Agro-Science Journal of Tropical Agriculture, Food, Environment and Extension Volume 12 Number 2 Mav 2013 pp. $40-44$

ISSN1119-7455

\title{
CONSTRUCTION AND PERFORMANCE EVALUATION OF AN ON-FARM SCALE SOLID STATE FERMENTER
}

\author{
Ezekiel, O. O. and Aworh, O.C. \\ Department of Food Technology, University of Ibadan, Ibadan, Nigeria
}

\begin{abstract}
The protein enrichment of cassava peel using solid state fermentation (SSF) was studied on both laboratory and on-farm scales using Trichoderma viride as a starter culture. The fermentation of cassava peel was carried out using cassava peel with particle size $4.00>p>3.35 \mathrm{~mm}$, initial moisture content of $60 \%$ at $\mathrm{pH} 6.0,30^{\circ} \mathrm{C}$ incubation temperature with ammonium sulphate (10g $\mathrm{N} / \mathrm{kg}$ substrate) as additional nitrogen source for 8 days at the laboratory scale and $28-30^{\circ} \mathrm{C}$ at the on-farm scale. A high relative humidity of $90-95 \%$ was maintained throughout the fermentation period. The fermented peel was oven-dried at $60^{\circ} \mathrm{C}$, ground and analysed. for crude protein, true protein, crude fat, crude fibre, ash, carbohydrate, starch and cyanide using standard methods. Comparable values were obtained for laboratory and on-farm scale fermentation. However, the on-farm technique yielded higher protein enrichment compared with laboratory experiments. Cassava peel fermented onfarm yielded $10.93 \%$ protein while laboratory scale yielded $10.43 \%$
\end{abstract}

Key words: cassava peel, laboratory scale, on-farm scale, protein enrichment, solid-state fermentation.

\section{INTRODUCTION}

Cassava (Manihot esculenta Crantz syn. Manihot utilissima Pohl) a staple food of the majority of people in tropical Africa, Central and South America (Nestel, 1973; Subrahmanyan, 1990), is often subjected to series of fermentations in the different countries to produce similar or different products (Akinrele, 1967). In Brazil, Costa Rica and Bolivia, farina is often the end product while in tropical Africa gari, fufu, lafun, chiwangue and myondo are produced from cassava (Subrahmanyan, 1990, Giraud et al., 1991). The various production processes are usually accompanied with some waste products that act as environmental pollutants (Onilude, 1996).

Cassava peels, leaves and starch residues constitute $25 \%$ of the cassava plant (Iyayi and Losel, 2001). These are usually discarded as wastes after harvesting and processing, with limited utilization due to low protein, high crude fibre and cyanide contents (Iyayi and Tewe, 1988). The peel is about 10-20\% of the tuber and is available all-year- round in Nigeria with an annual yield of approximately 4 million metric tonnes from the processing of cassava tuber (Hahn and Keyser, 1985). Little attention has been paid to the handling of the large quantity of cassava wastes that generated. Solid state fermentation (SSF) is a veritable way of converting such wastes to wealth. Microorganisms have the ability to upgrade low protein plant material to high protein feed (Rajoka, 2005). Largescale fermentation of methanol, starch and molassesbased media has proved economically viable for the production of animal feed and human food (Rosenberg 1993; Hongpattarakere and H-kittim, 1995; Paul et al. 2002).

Processing by SSF is a relevant, initial approach to lignocellulose bioconversion appropriate for developing countries. It offers the possibility of using by-products and wastes from food and agricultural industries (Gomez et al., 2005) for food, feed, chemicals and fuel.The greatest socio-economical potential of SSF is the raising of living standards through the production of protein rich foods for human consumption (Raimbault, 1998). This can be achieved 
by exploring two alternatives: production of proteinenriched fermented foods for direct human consumption and production of fermented materials for animal feeding.

Starch substrate protein-enriched by SSF could be fed to monogastric animals or poultry.

Bacteria, yeasts and fungi can grow on solid substrate and find application in SSF processes. Filamentous fungi are the most important group of microorganisms used in solid-state process owing to their physiological, enzymological and biochemical properties (Raimbault, 1998). Trichoderma viride, a filamentous fungus, has been previously used in the fermentation of several food processing wastes De Gregorio et al. (2002) fermented lemon pulp with $T$. viride and A. niger by slurry-state fermentation and reported higher protein content in the residue with $T$. viride than with A. niger. Palm-tree leaflets and midribs, both of very low protein content, when chemically hydrolysed and used for the growth of $T$. viride were enriched with protein (Abou-Zeid, 1991).

Many high value products such as enzymes, primary and secondary metabolites, could be produced in SSF. However, improvements in engineering and socio-economic aspects are required because processes must use cheap substrates available locally, low technology adaptable to rural areas, and simplified processes (Raimbault, 1998).

The objective of this work was to evaluate the performance of a constructed on-farm scale fermenter, for the fermentation of cassava peel by comparing it with laboratory scale using Trichoderme viride as a starter culture.

\section{MATERIALS AND METHODS}

\section{Materials of Construction}

The materials used in the construction of the solid state fermenter were:
Aluminium 2-inch square pipes
Galvanized steel sieve
Pipex glass
Aluminium long-span sheet
Hinges
Rivet pins
$3 / 4$ inch diameter plastic pipes
Formica sheet
$0.033 \mathrm{hp} \mathrm{fan}$

The fermenter was constructed based on the procedure described by Noorhom et al. (1992) for fermenting cassava pulp using Aspergillus niger as a starter culture. The size of the perforations on the tray was determined based on preliminary findings from the laboratory experiments for the appropriate sample particle size which was found to be between 3.35 and $4.00 \mathrm{~mm}$.
The following points were considered in the design of the fermenter: capacity of the fan to give proper aeration constant supply of water to be supplied to give relative humidity of $90-95 \%$

\section{Performance Evaluation}

The peel from fresh cassava tubers, variety TME I, obtained from a farm at Ajibade village in Akinyele Local Government Area, Ibadan was used for this study.

\section{Micro-organism}

The filamentous fungi T. viride ATCC 36316 was obtained from American Type Culture Collection.

\section{Maintenance Medium}

T. viride ATCC 36316 was maintained on malt extract agar slants and stored at $4^{\circ} \mathrm{C}$. The organism was subcultured once every 3 months.

\section{Inoculum Preparation}

The fungus was sub-cultured on malt extract agar in petri dishes for 5 days. Spore suspension containing approximately $3 \times 10^{6}$ spores per $\mathrm{ml}$ was prepared in Ringer solution.

\section{Solid State Fermentation of Cassava peel: Laboratory Scale}

Solid state fermentation of cassava peel on laboratory scale was carried out using cassava peel with particle size $4.00>p>3.35 \mathrm{~mm}$, initial moisture content of $60 \%$ at $\mathrm{pH} 6.0,30^{\circ} \mathrm{C}$ incubation temperature with ammonium sulphate (10g N / $\mathrm{kg}$ substrate) as additional nitrogen source. These conditions were chosen based on the results of previous work carried out on optimisation of processing conditions for protein enrichment of cassava peel (Awoyele, 2010). Fermentation was allowed for 8 days. At the end of fermentation, samples were dried at $60^{\circ} \mathrm{C}$ for subsequent analysis. Figure 1 shows the flowchart for the fermentation procedure.

\section{Solid State Fermentation of Cassava Peel: On-Farm Scale \\ Perforated mesh trays (Figures 2) with an area} of $3920 \mathrm{~cm}^{2}$ were stacked leaving a gap of $15.5 \mathrm{~mm}$ between trays. The stack of trays loaded with uniformly spread inoculated cassava peel was covered with sacks and water, supplied through perforated pipes, was made to drip onto the sacks. The cassava peel was prepared for fermentation as in the laboratory scale experiment.

\section{Compositional Analysis of Cassava Peel}


Moisture content of the cassava peel was determined by drying at $105^{\circ} \mathrm{C}$ to constant weight (AOAC, 1995). The crude protein was by Kjeldahl method (total nitrogen x 6.25), crude fibre, fat, ash, carbohydrates (estimated by difference), total dietary fibre and gross metabolizable energy were quantified as described by AOAC methods (AOAC, 1995). True protein content was determined by the method of Lowry (1951). Total cyanide of dried samples was determined by phosphoric acid extraction, hydrolysis of cyanogenic glucosides with linamarase from cassava, followed by colorimetric determination of cyanide (Cooke, 1978).

\section{RESULTS AND DISCUSSION Features of the Fermenter}

The fermenter has the shape of a cabinet with fixed racks and capacity for five perforated trays made with $0.2 \mathrm{~mm}$ gauge stainless steel pipes. (Figure 2) Each tray can hold up to $400 \mathrm{~g}$ of substrate per fermentation batch.

The trays are $70 \mathrm{~cm}$ by $56 \mathrm{~cm}$ with a thickness of 5.5 $\mathrm{cm}$ each while each perforation has a diameter of 2 $\mathrm{mm}$. Perforated pipes were installed at the top of the fermenter to supply water in order to create and maintain an environment with a high relative humidity during the fermentation process. At the bottom of all the trays was placed a fixed aluminium tray with a small outlet for removing overflow water being supplied. The fermenter was set on stands for stability. A portable electric fan with a capacity of $1 / 30 \mathrm{hp}$ was placed at the bottom of the bottom of the stack of trays in order to maintain proper aeration. The fermenter achieved temperature in the range of $28-30^{\circ} \mathrm{C}$.

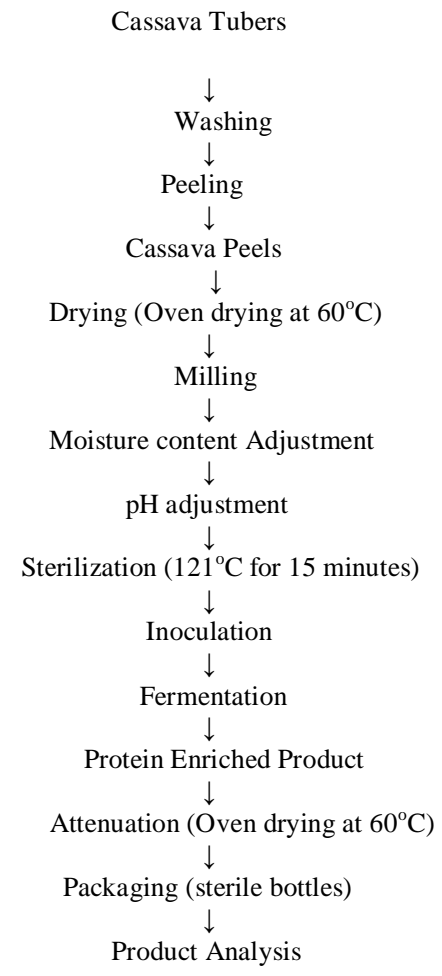

Figure 1: Flow Chart for Protein Enrichment of Cassava Peels 


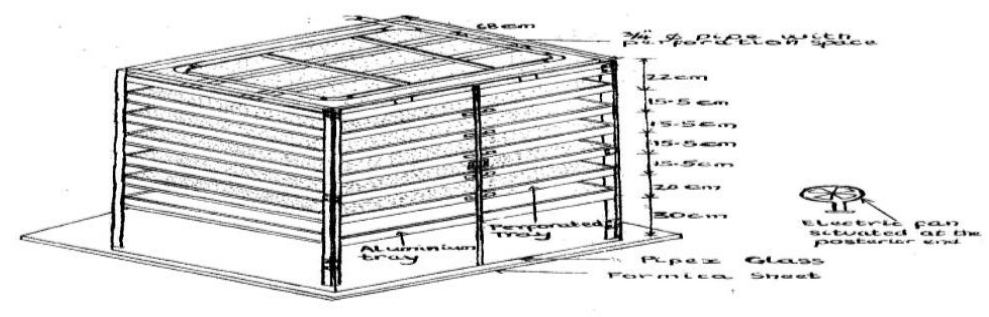

Figure 2: Schematic Isometric Projection of On-Farm Scale Fermenter

Table 1: Chemical Composition of Trichoderma viride Enriched Cassava Peel during Solid-State Fermentation at Laboratory and On-Farm Scales.

\begin{tabular}{llll}
\hline & \multicolumn{2}{c}{ Fermented Cassava Peel Samples } \\
Composition $(\%)$ & Unfermented cassava peel & $\begin{array}{l}\text { Laboratory } \\
\text { Scale }\end{array}$ & $\begin{array}{l}\text { On- farm } \\
\text { Scale }\end{array}$ \\
\hline Crude Protein & $4.21^{\mathrm{b}}$ & $10.43^{\mathrm{a}}$ & $10.93^{\mathrm{a}}$ \\
True Protein & $1.36^{\mathrm{b}}$ & $7.90^{\mathrm{a}}$ & $8.60^{\mathrm{a}}$ \\
Moisture & $8.73^{\mathrm{a}}$ & $7.69^{\mathrm{a}}$ & $7.72^{\mathrm{a}}$ \\
Crude Fat & $1.37^{\mathrm{a}}$ & $1.20^{\mathrm{b}}$ & $1.22^{\mathrm{b}}$ \\
Crude Fibre & $8.46^{\mathrm{a}}$ & $6.37^{\mathrm{b}}$ & $6.15^{\mathrm{b}}$ \\
Ash & $3.27^{\mathrm{b}}$ & $7.82^{\mathrm{a}}$ & $7.83^{\mathrm{a}}$ \\
Carbohydrate by Difference. & $91.15^{\mathrm{a}}$ & $80.55^{\mathrm{b}}$ & $80.02^{\mathrm{b}}$ \\
HCN(mg/100g) & $0.72^{\mathrm{a}}$ & $0.21^{\mathrm{b}}$ & $0.23^{\mathrm{b}}$ \\
Starch & $51.93^{\mathrm{a}}$ & $34.59^{\mathrm{b}}$ & $32.42^{\mathrm{c}}$ \\
Gross Calories (kcal/100g) & $393.79^{\mathrm{a}}$ & $374.72^{\mathrm{b}}$ & $374.78^{\mathrm{b}}$ \\
Total Dietary Fibre & $24.96^{\mathrm{a}}$ & $13.90^{\mathrm{b}}$ & $11.92^{\mathrm{c}}$ \\
\hline
\end{tabular}

Results are expressed on a dry matter basis. Each value is a mean of three independent experiments.

Means followed by the same superscript in the same row are not significantly different $(p \leq 0.05)$

\section{Compositional Analysis of Fermented Cassava Peel at Laboratory and On-Farm Scale}

At the laboratory scale, crude protein, true protein and ash increased from 4.21 to $10.43 \%, 1.36$ to $7.90 \%, 3.27$ to $7.82 \%$, respectively while crude fat, crude fibre, carbohydrate, cyanide, starch, gross calorie and total dietary fibre reduced from 1.37 to $1.20,8.46$ to $6.37 \%, 91.15$ to $80.55 \% 0.72$ to $0.21 \mathrm{mg} / 100 \mathrm{~g}$, 51.93 to $34.59 \%, 374.72 \mathrm{kcal} / 100 \mathrm{~g}$ and 24.96 to 13.90 $\%$ respectively. At the on-farm scale crude protein, true protein, and ash increased to $10.93 \%, 8.60 \%$ and $7.83 \%$ respectively while crude fat, crude fibre, carbohydrate, cyanide, starch and total dietary fibre reduced to $1.22 \%, 6.15 \%, 80.02 \%, 0.23 \mathrm{mg} / 100 \mathrm{~g}$, $32.42 \%, 374.78 \mathrm{kcal} / 100 \mathrm{~g}$ and $11.92 \%$ respectively. Higher crude protein, true protein and ash content were observed in the on-farm scale when compared with the laboratory scale. However, there was no significant ( $\mathrm{p}$ $\leq 0.05$ ) difference in the measured parameters between laboratory and on farm scale fermented cassava peel except in the starch and total dietary fibre.
This is in agreement with the results of Noorhom et al (1992) during the solid state fermentation of cassava with Aspergillus niger at laboratory and on-farm scale. The higher protein content may be due to better aereation provided by the fan as well as maintenance of high relative humidity in the fermenter (Noorhom et al., 1992). The increase in the protein content could also be attributed to the possible secretion of some extracellular enzymes (proteins) such as amylases, linamarase and cellulose (Oboh et al., 2003) into the cassava mash by the fermenting organisms (Raimbault, 1998), as well as increase in the growth and proliferation of the fungi complex in the form of single cell proteins (Antai and Mbongo, 1994; Oboh et al., 2000). However, there were significance differences $(\mathrm{p} \leq 0.05)$ in the chemical composition of unfermented and fermented cassava peel. 


\section{CONCLUSION}

The on-farm scale fermenter achieved fermentation of cassava peel comparable to laboratory scale but with an advantage of larger capacity in each fermentation batch. Consequently, an on-farm scale fermenter can be used in rural areas to handle relatively large amount of cassava peel in processing sites and rural farm settlements. The fermenter can also be adapted as a solid- state fermentation frame for many other indigenous substrates.

Further studies on improvement of the constructed onfarm scale fermenter in terms of sterility, process control and size should be carried out.

\section{ACKNOWLEDGEMENT}

The authors acknowledge the funding support of the University of Ibadan Senate Research Grant given to O.C Aworh to carry out this project.

\section{REFERENCES}

Abou-Zeid A. A. (1991). Increasing the protein content of palm by-products. Bioresource Technology 37: 239-242.

Akinrele, I.A.(1967). Further studies on the fermentation of cassava. Research. Report No.20 of the Federal Institute of Industrial Research, Oshodi, Nigeria. Antai, S.P. and Mbongo, P.M. (1994). Utilization of cassava peels as substrate for crude protein formation. Plant Foods Human Nutrition 46(4): 345-351.

A.O.A.C. (1990). Official methods of analysis. 13th edition. Association of Official Analytical Chemists. Washington, DC. Awoyele, O.O. (2010). Fermentation of cassava peel with Trichoderma viride and Candida utilis for protein enrichment. Ph.D Thesis Department of Food Technology, University of Ibadan, Ibadan, Nigeria.

Cooke R.D. (1978). An enzymatic assay for total cyanide content of cassava (manihot esculanta Crantz). Journal of Science Food and Agriculture 29:345-352.

De Gregorio, A., Mandalari, G., Arena N, Nucita, F., Tripodo, M.M. and Lo Curto, R.B. (2002). Single cell protein and crude pectinase production by slurry-state fermentation of lemon pulps. Bioresource Technology 83(2):89-94.

Dubois, M., Gilles, K. A., Hamilton, J. K., Rebers, P. A. and Smith, F. (1956). Colorimetric method for determination of sugars and related substances. Analytical Chemistry 28.3: 250356.
Giraud, E., Brauman, A., Keleke, S., Lelong, B.and Raimbult, M. (1991). Isolation and physiological study of an amylolytic strain of Lactobacillus Plantarum. Applied Microbiology and Biotechnology 36: 379-383.

Gomez, J., Pazos, M. Couto, S.R. and Sanroman, M.A. (2005). Chestnut shell and barley bran as potential substrates for laccase production by Coriolopsis rigida under solid-state conditions. Journal of Food Engineering 68: 315-319.

Hahn, S. K. and Keyser, J. (1985).Cassava: A basic food in Africa. Outlook on Agriculture. 4: 95100.

Hongpattarakere, T. and H-Kittikun, A. (1995). Optimization of single cell-protein production from cassava starch using Schwanniomyces castelli. World Journal of Microbiology and Biotechnology 11, 607-609.

Iyayi, E.A.and Losel D.M. (2001). Protein Enrichment of cassava By-Products through Solid State Fermentation by Fungi.The Journal of Food Technology in Africa 6.4: 116-118.

Iyayi, E.A. and Tewe, O.O. (1988). Effect of protein deficiency in utilization of cassava peel by growing pigs. Cassava as Livestock feed in Africa. Eds.S.K. Haha, L. Reynolds and G.N. Egbunike.Proceedings of the IITA/ILCA/University of Ibadan workshop.14-18 November. 54-59.

Lowry, O. H., Rosebrough, N. J., Farr, A. L., Randall, R. J. (1951). Protein Measurement with Folinphenol reagent. Journal of Biological Chemistry 193: 265-275.

Nestel, B. 1973. Current utilization and future potential for cassava. Chronic Cassava Toxicity. Eds. Nestel, B., Macintyre, R. Ottawa: International Development Centre.11-26.

Noomhorm, A., Ilangantileke, S. and Bautista, M.B. (1992). Factors in the Protein Enrichment of Cassava by Solid State Fermentation. Journal of Food and Agriculture 52: 117-123.

Oboh, G., Akindahunsi, A.A. and Oshodi, A.A. (2000). Nutrient and anti-nutrient content of Aspergillus niger fermented cassava products (flour and garri). Journal of Food Composition and Analysis 15(5): 617-622.

Oboh, G. and Akindahunsi, A. A. (2003). Biochemical changes in cassava products (flour and garri) subjected to Saccharomyces cerevisae solid media fermentation. Food Chemistry 82(4):559-602.

Onilude, A.A., (1994). Production, characterisation and utilization of some dietary fiber degrading enzymes as additives in Broiler diets. Ph.D. 
Thesis, Department of Botany and Microbiology University of Ibadan, Nigeria.

Paul, D., Mukhopadhyay, R., Chatterjee, B. P and Guha, A. K. (2002). Nutritional profile of food yeast Kluyveromyces fragilis biomass grown on whey. Applied Biochemistry and Biotechnology 97: 209-218

Raimbault, M. (1998). General and Microbiological aspects of Solid Substrate Fermentation. Electronic Journal of Biotechnology: Process Biotechnology 1: 3. Accessed 23/03/2006

Rajoka, M. I. (2005). Production of single cell protein through fermentation of a perennial grass grown on saline lands with Cellulomonas biazotea. World Journal of Microbiology \& Biotechnology 21:207-211

Rosenberg, E. (1993). Exploiting microbial growth on hydrocarbons: new markets. Trends in Biotechnology 11: 419-424.

Subrahmanyan, D. (1990). Processing: Fermented Foods of Cassava. Food Laboratory News No.21, 6 (3): 9-12. 